\title{
Antibacterial activities of rosemary essential oils and their components against pathogenic bacteria
}

\begin{abstract}
There are many known essential oils, of which only 300 are commercially important for different types of industry. Antimicrobials are used in food for two main reasons: to control natural spoilage processes and to prevent/control growth of micro-organisms, including pathogenic microorganisms. The aim of this review was to investigate antibacterial effects of rosemary essential oils (EOs) on some Gram-positive and Gram-negative bacteria: Staphylococcus aureus, Bacillus subtilis, Escherichia coli, Proteus vulgaris, Pseudomonas aeruginosa. Listeria monocytogenes, Salmonella enteritidis, Salmonella typhimurium. Rosmarinus officinalis essential oil is very important for its medicinal uses and its powerful antibacterial, cytotoxic, anti-mutagenic, antioxidant, anti-phlogistic and chemopreventive properties. The antimicrobial and other biological activities of rosemary essential oil are directly correlated with the presence of bioactive volatile components. To this end, one possibility has been the use of rosemary essential oils (EOs) and the compounds found there in as alternative antimicrobial food preservatives. The future will see investigation of food applications of the naturally occurring antimicrobials, especially the effectiveness of rosemary EOs, individually and in combination with other parts of plant extract, other effective EOs and other food-processing techniques.
\end{abstract}

Volume 3 Issue 4 - 2018

\author{
Jasmina Stojiljkovic,' Metodija Trajchev, ${ }^{2}$ \\ Dimitar Nakov, ${ }^{2}$ Milena Petrovska ${ }^{3}$ \\ 'Food Technology, College of Applied Studies, Republic of Serbia \\ ${ }^{2}$ Faculty of Agricultural Science and Food, University St. Cyril \\ and Methodius, Republic of Macedonia \\ ${ }^{3}$ Faculty of Medicine, University St. Cyril and Methodius, \\ Republic of Macedonia
}

Correspondence: Jasmina Stojiljkovic, MSc of Technological Microbiology, Coordinator of the department Food Technology, College of Applied Studies, Filipa Filipovica 20,Vranje, Republic of Serbia, Tel +38I6 3108 6667, Fax +38II 7404 66I, Email jasminavvranje@yahoo.com

Received: February 05, 2018 | Published:September 18, 2018

Keywords: antibacterial effect, essential oil, rosemary, pathogenic bacteria

Abbreviations: EOLs, essential oils; ATP, adenosine three phosphate; MIC, minimum inhibitory concentrations; IZ, inhibition zone; ATCC, american type culture collection; NCTC, national collection of type cultures, a culture collection of public health england

\section{Introduction}

Plants producing essential oils belong to various genera in about 60 families, including Alliaceae, Apiaceae, Asteraceae, Lamiaceae, Myrtaceae, Poaceae, and Rutaceae. ${ }^{1}$ Plant essential oils are a potentially useful source of antimicrobial compounds. ${ }^{2}$ Aromatic plants and their essential oils (EOs) have been used since ancient times in food, agriculture, medicine, cosmetic applications, as condiments and spices, in therapeutic uses, as antimicrobials, as flavoring agents, and in storage as insecticidal agents. ${ }^{3}$ The use of plant essential oils has been the new focus of agricultural and food industries as an alternative to synthetic food additives for inactivation of microorganisms such as pathogenic and spoilage bacteria that cause food safety and public health-related issues during transportation, storage, shelf-life, and packaging. ${ }^{4}$ Antimicrobials are used in food for two main reasons: to control natural spoilage processes (food preservation), and to prevent/control growth of microorganisms, including pathogenic microorganisms (food safety). ${ }^{5}$ Natural antibacterial essential oils have gained an increased interest and are considered as safe and ecofriendly alternative to control foodborne bacteria and other pathogenic microorganisms, notably drugs resistant ones. ${ }^{6,7}$ In food processing, it is important that proper measures are taken to ensure the safety and stability of products for the duration of their shelf life. ${ }^{8}$

\section{Discussion}

\section{Mechanisms of action of the EOs on pathogenic bacteria}

Some studies have demonstrated that whole EOs usually have higher antibacterial activity than the mixtures of their major components, suggesting that the minor components are critical to the synergistic activity, though antagonistic and additive effects have also been observed. ${ }^{9}, 10$ EOs derived from spices and plants have antimicrobial activity against Listeria monocytogenes, Salmonella typhimurium, Escherichia coli O157:H7, Shigella dysenteriae, Bacillus cereus and Staphylococcus aureus at levels between 0.2 and $10 \mu \mathrm{L} / \mathrm{mL} .{ }^{11}$ Determination of the antimicrobial activity of 17 essential oils against Escherichia coli O157:H7 and Salmonella enterica in apple juices indicated that the reduction in the number of bacteria can reach $50 \% .{ }^{12}$ Considering the large number of different groups of chemical compounds present in EOs, it is most likely that their antibacterial activity is not attributable to one specific mechanism but that there are several targets in the cell. An important characteristic of EOs and their components is their hydrophobicity, which enables them to partition in the lipids of the bacterial cell membrane and mitochondria, disturbing the structures and rendering them more permeable. Leakage of ions and other cell contents can then occur and causes the death of bacterial cell. Generally, the EOs possessing the strongest antibacterial properties against food borne pathogens contain a high percentage of phenolic compounds such as carvacrol, eugenol and thymol. ${ }^{11}$ The mechanisms of action of the EOs include the degradation of the cell wall, damaging the cytoplasmic membrane, 
cytoplasm coagulation, damaging the membrane proteins, increased permeability leading to leakage of the cell contents, reducing the proton motive force, reducing the intracellular ATP (Adenosine Three Phosphate) pool via decreased ATP synthesis and augmented hydrolysis that is separate from the increased membrane permeability and reducing the membrane potential via increased membrane permeability. The cell wall of Gram-negative bacteria is more resistant to the activity of EOs and their components. The Gram-negative cell wall does not allow for the entrance of hydrophobic molecules as readily as Gram-positive bacteria; thus, EOs are less able to affect the cell growth of the Gram-negative bacteria. ${ }^{13}$ Interaction of essential oils with microbial cell membranes results in growth inhibition of some Gram-positive and Gram-negative bacteria. ${ }^{14}$ It has been reported that Gram-positive bacteria appear to be more susceptible to the antibacterial properties of essential oil compounds than Gramnegative bacteria. This is expected, as Gram-negative bacteria have an outer layer surrounding their cell wall, limiting the access of hydrophobic compounds. Gram-negative bacteria are usually more resistant to the plant-origin antimicrobials and even show no effect, compared to Gram-positive bacteria. ${ }^{15,16}$

\section{Essential oil of rosemary}

Rosemary (Rosmarinus officinalis L.) is of considerable importance in term of its great an important medicinal and aromatic value. This plant belongs to Lamiaceae family. Rosemary is a perennial evergreen herb with fragrant needlelike leaves. ${ }^{17}$ Rosemary herbs have been widely used in the traditional medicine and cosmetics. They are also used as flavouring agents in foods. ${ }^{18}$ Rosmarinus officinalis essential oil is also important for its medicinal uses and its powerful antibacterial, cytotoxic, antimutagenic, antioxidant, antiphlogistic and chemopreventive properties. ${ }^{19}$ The major components determined in R. officinalis essential oil were 1,8-cineol (38.5\%), camphor (17.1\%), $\alpha$-pinene (12.3\%), limonene (6.23\%), camphene (6.00\%) and linalool $(5.70 \%){ }^{20}$ The chemical analysis of rosemary essential oil by GC has identified 11 compounds which they make $78.25 \%$ rosemary essential oil. Major components of the essential oil include alpha-pinene (23.93\%), camphen $(8.7 \%)$, camphor $(10.97 \%)$, verbenon $(15.44 \%)$, p-cymene $(7.48 \%)$ and 3-Octanone $(5.63 \%))^{21}$

\section{The antimicrobial activity of rosemary oil}

In the Italian territory, Abruzzo is one of the central area regions characterized by a multitude ofenvironments and microclimates and with the richest flora of Italy and the Mediterranean basin. ${ }^{22}$ In the Abruzzo territory, different plant species are cultivated and exploited for their therapeutic and alimentary properties; ${ }^{23}$ among them, Rosmarinus officinalis, Origanum vulgare, Salvia officinalis, Mentha piperita, Allium sativum, Foeniculum vulgare, Satureja montana, Thymus vulgaris, and Coriandrum sativum.

The study of ${ }^{24}$ assessed the effect of the combined application of essential oils (EOs) from Origanum vulgare L. - oregano and Rosmarinus officinalis L. - rosemary, alone or in combination at subinhibitory concentrations, against three pathogenic bacteria that are associated with fresh leafy vegetables: Listeria monocytogenes (L. monocytogenes), Escherichia coli (E. coli) and Salmonella enterica Serovar Enteritidis (S. Enteritidis). The minimum inhibitory concentration MIC of oregano was $0.6 \mathrm{~mL} / \mathrm{mL}$ against the test strains either in single and mixed inoculum. The MIC of rosemary was $5 \mathrm{~mL} /$ $\mathrm{mL}$ against L. monocytogenes and $E$. coli and $10 \mathrm{~mL} / \mathrm{mL}$ against $\mathrm{S}$. Enteritidis in single inocula, whereas it was $10 \mathrm{~mL} / \mathrm{mL}$ against the mixed inoculum. The fractional inhibitory concentration index of the combined EOs was 0.5 against the mixed bacterial inoculum, which suggested a synergic interaction. The incorporation of oregano and rosemary alone (MIC) or combined at different subinhibitory concentrations in vegetable broth resulted in a decrease in the viable cell counts of all test strains over $24 \mathrm{~h}$. After a 10-min treatment, the oregano and rosemary, either alone or in combination at different sub inhibitory concentrations, caused similar decrease $(p>0.05)$ in the counts of all assessed groups (or family) of spoilage microorganisms. The decrease in counts of mesophilic bacteria, enterobacteria and fungi was always close to 3.0, 2.5 and $3.1 \log$ cycles, respectively. Overall, the exposure of the EOs for 10 min caused a greater decrease $(\mathrm{p}<0.05)$ in spoilage native flora counts in comparison to $5 \mathrm{~min}$. The essential oil of rosemary were tested against eight strains of bacteria: Staphylococcus aureus (NCTC 6571), Bacillus cereus (ATCC 11778), Bacillus subtilis (NCTC 10400), Bacillus pumilis (wild type), Pseudomonas aeruginosa (NCTC 1662), Salmonella poona (NCTC 4840), Escherichia coli (ATCC 8739) and amphicilin resistant Escherichia coli (NCTC 10418). The results from the disc diffusion assay followed by modified resazurin assay indicated that the tested essential oil showed higher antibacterial activity against Gram-positive bacteria (IZ 18.0- 24.2; MIC 0.20-0.48mg mL $\mathrm{mL}^{-1}$ ) than against Gram-negative bacteria (IZ 12.8-17.5; MIC 1.16-1.72 $\left.\mathrm{mg} \mathrm{mL}{ }^{-1}\right){ }^{25}$ Rosmarinus officinalis Linn. (rosemary) hydroalcoholic extract was assayed against Streptococcus mitis, Streptococcus sanguinis, Streptococcus mutans, Streptococcus sobrinus and Lactobacillus casei standard strains, and its antimicrobial activity was proven in all tests, except against $S$. mitis. ${ }^{26}$ The aim of the study of ${ }^{27}$ was to evaluate antibacterial properties of commercial essential oils (rosemary, caraway and fennel) to reduce the number of Staphylococcus aureus and Escherichia coli. The result of experiments showed that essential oils contained in microbiological media significantly reduced the number of $S$. aureus and $E$. coli cells. The best antibacterial properties possessed caraway oil: $1 \mathrm{mg} / \mathrm{g}$ for $\mathrm{S}$. aureus and $10 \mathrm{mg} / \mathrm{g}$ for $E$. coli, weaker rosemary $(5 \mathrm{mg} / \mathrm{g})$ and fennel $(20 \mathrm{mg} / \mathrm{g})$ oils. The combination of clove and rosemary essential oils produced an additive effect against the Gram-positive and Gramnegative bacteria, namely Staphylococcus aureus, Staphylococcus epidermidis, Bacillus subtilis, Escherichia coli, Proteus vulgaris and Pseudomonas aeruginosa. ${ }^{28}$ Essential oils Origanum vulgare and Rosmarinus officinalis combined at sub-inhibitory concentrations were effective in inhibiting the growth and survival of pathogenic and spoilage microorganisms associated to minimally processed vegetables, although the underlying mode of action remains to be explored in the future. Sensory evaluation suggested that application of the essential oils in mixture at sub-inhibitory concentrations as sanitizer in vegetables would be acceptable to consumers, mainly when regarded a more extended storage time..$^{29}$ The inhibitory effects of the hydrosols of thyme, black cumin, sage, rosemary, and bay leaf against S. typhimurium and Escherichia coli $\mathrm{O} 157: \mathrm{H} 7$ were shown in carrots and apples. Thyme hydrosol had the highest antibacterial effect on both Salmonella typhimurium and Escherichia coli O157:H7 counts. ${ }^{30}$ Among Gram-negative, Salmonella spp. was inhibited mostly by EOs of thyme $(500 \mathrm{ppm})$, rosemary $(5000 \mathrm{ppm})$ and garlic $(20000 \mathrm{ppm}), \mathrm{E}$. coli was mostly inhibited by thyme (250ppm), cinnamon (2500ppm) and cumin $(2500 \mathrm{ppm}){ }^{31}$

\section{Conclusion}

Natural antimicrobial extracts from herbs, spices, and plants can be used in food industry to prevent growth of foodborne pathogens and food spoilage microorganisms and to enhance the shelf life and stability. Due to the antioxidant and antimicrobial effects of natural ingredients, they can be a good alternative to classical food 
preservation methods and usage of chemical preservatives and food additives. These plant products have shown to reduce the growth of both Gram-positive and Gram-negative microorganisms including foodborne pathogens.

Three main factors can influence the results of a test of the antimicrobial activity of plant oil: the composition and solubility of the oil, the microorganism, and the method of growing and enumerating the surviving bacteria. Rosmarinus officinalis essential oil is also important for its medicinal uses and its powerful antibacterial, cytotoxic, anti-mutagenic, antioxidant, anti-phlogistic and chemopreventive properties.

The major components determined in $R$. officinalis essential oil were 1, 8-cineol, camphor, $\alpha$-pinene, limonene, camphene and linalool. Rosmarinus officinalis essential oil showed higher antibacterial activity against Gram-positive bacteria than against Gram-negative bacteria.

\section{Acknowledgements}

None.

\section{Conflict of Interest}

The author declares that there is no conflict of interest.

\section{References}

1. Raut JS, Karuppayil SM. A status review on the medicinal properties of essential oils. Industrial Crops and Products. 2014;62:250-264.

2. Friedman M, Henika RP, Mandrell ER. Bactericidal Activities of Plant Essential Oils and Some of Their Isolated Constituents against Campylobacter jejuni, Escherichia coli, Listeria monocytogenes, and Salmonella enterica. J Food Prot. 2002;65(10):1545-1560.

3. Bakkali F, Averbeck S, Averbeck D, et al. Biological effects of essential oils-a review. Food and Chemical Toxicology. 2008;46(2):446-475.

4. Smith-Palmer A, Stewart J, Fyfe L. The potential application of plant essential oils as natural food preservatives in soft cheese. Food Microbiology. 2001;18(4):463-470.

5. Tajkarimi MM, Ibrahim AS, Cliver OD. Antimicrobial herb and spice compounds in food. Food Control. 2010;21(9):1199-1218.

6. Yap PSX, Lim SHE, Hu CP, et al. Combination of essential oils and antibiotics reduce antibiotic resistance in plasmid-conferred multidrugresistant bacteria. Phytomedicine. 2013;20(8-9):710-713

7. Yap PS, Yiap BC, Ping HC, et al. Essential oils, a new horizon in combating bacterial antibiotic resistance. Open Microbiol J. 2014;8:614.

8. Souza de LE. The effects of sublethal doses of essential oils and their constituents on antimicrobial susceptibility and antibiotic resistance among food-related bacteria: A review. Trends in Food Science \& Technology. 2016;56:1-12.

9. Gill AO, Delaquis P, Russo P, et al. Evaluation of antilisterial action of cilantro oil on vacuum packed ham. Int J Food Microbiol. 2002;73(1):8392.

10. Mourey A, Canillac N. Anti-Listeria monocytogenes activity of essential oils components of conifers. Food Control. 2002;13(4-5):289-292.

11. Burt S. Essential oils: Their antibacterial properties and potentia applications in foods-A review. Int J Food Microbiol. 2004;94(3):223253
12. Friedman M, Henika PR, Levin CE, et al. Antibacterial activities of plant essential oils and their components against Escherichia coli O157:H7 and Salmonella enterica in apple juice. J Agric Food Chem 2004;52(19):6042-6048.

13. Nazzaro F, Fratianni F, De Martino L, et al. Effect of Essential Oils on Pathogenic Bacteria. Pharma. 2013;6(12):1451-1474.

14. Rivera Calo J, Crandall PG, O’Bryan CA, et al. Essential oils as antimicrobials in food systems-a review. Food Control. 2015;54:111119.

15. Rameshkumar KB, George V, Shiburaj S. Chemical constituents and antibacterial activity of the leaf oil of Cinnamomum chemungianum Mohan et Henry. Journal of Essential Oil Research. 2007;19:98-100.

16. Stefanello MEA, Cervi AC, Ito IY, Salvador, MJ, Wisniewski A, et al. Chemical composition and antimicrobial activity of essential oils of Eugenia chlorophylla (Myrtaceae). Journal of Essential Oil Research. 2008;20(1):75-78.

17. Bousbia N, Vian MA, Ferhat MA, et al. Comparison of two isolation methods for essential oil from rosemary leaves: Hydrodistillation and microwave hydrodiffusion and gravity. Food Chem. 2008;14:355-362.

18. Pintore G, Usai M, Bradesi $\mathrm{P}$, et al. Chemical composition and antimicrobial activity of Rosmarinus officinalis L. oils from Sardinia and Corsica. Flav Frag J. 2002;17(1):15-19.

19. Celiktas OY, Kocabas EEH, Bedir E, et al. Antimicrobial activities of methanol extracts and essential oils of Rosmarinus oficinalis, depending on location and seasonal variations. Food Chem. 2007;100(2):553-559.

20. Hussain AI, Anwar F, Hussain-Sherazi ST, et al. Chemical composition, antioxidant and antimicrobial activities of basil (Ocimum basilicum) essential oils depends on seasonal variations. Food Chem. 2008;108(3):986-995.

21. Mehrsorosh H, Gavanji S, Larki B, et al. Essential oil composition and antimicrobial screening of some Iranian herbal plants on Pectobacterium carotovorum. Global NEST Journal. 2014;16(2):240-251.

22. Silveri A, Manzi A. Horticultural biodiversity and gardening in the region of Abruzzo. In: Bailey A, Eyzaguirre P, Maggioni L, editors. Crop Genetic Resources in European Home Gardens. Proceedings of a Workshop, Ljubljana. Italy: Bioversity International; 2009. p. 26-36.

23. Guarrera PM. Food medicine and minor nourishment in the folk traditions of Central Italy (Marche, Abruzzo ans Latium). Fitoterapia. 2003; 74:515-544

24. Barbosa IM, da Costa Medeiros JA, Kataryne de Oliveira AR, et al. Efficacy of the combined application of oregano and rosemary essential oils for the control of Escherichia coli, Listeria monocytogenes and Salmonella Enteritidis in leafy vegetables. Food Control. 2016;59:468477.

25. Hussain AI, Anwar F, Chatha SA, et al. Rosmarinus officinalis essential oil: antiproliferative, antioxidant and antibacterial activities. Braz J Microbiol. 2010;41(4):1070-1078.

26. Silva NCC, Fernandes Júnior A. Biological properties of medicinal plants: a review of their antimicrobial activity. The Journal of Venomous Animals and Toxins including Tropical Diseases. 2010;16(3):402-413.

27. Kwiatkowski P, Giedrys-Kalemba S, Mizielińska M, et al. Antibacterial activity of rosemary, caraway and fennel essential oils. Herba Polonica. 2015;61(4):31-39.

28. Faleiro ML. The mode of antibacterial action of essential oils. In: Méndez-Vilas A, editor. Microbial pathogens and strategies for combating them: science, technology and education. Spain: Formatex Research Center; 2013. p. 1143-1156. 
29. Azeredo GA, Stamford TL, Nunes PC. Combined application of essential oils from Origanum vulgare L. and Rosmarinus officinalis L. to inhibit bacteria and autochthonous microflora associated with minimally processed vegetables. Food Research International. 2011;44:15411548 .

30. Tornuk F, Cankurt H, Ozturk I, et al. Efficacy of various plant hydrosols as natural food sanitizers in reducing Escherichia coli O157:H7 and Salmonella Typhimurium on fresh cut carrots and apples. Int $\mathrm{J}$ Food Microbiol. 2011;148(1):30-35.
31. Diez JG. Essential oils of herbs and spices in dry-cured meat products. Universade de Trás-Os-Montese Alto Douro. 2015. 